Sustainability, Agri, Food and Environmental Research, (ISSN: 0719-3726), 10(X), 2022: http://dx.doi.org/

\title{
Bond strength properties of confined and unconfined coconut shell aggregate concrete by beam splice test.
}

\section{Propiedades de resistencia de adherencia del concreto agregado de cáscara de coco confinado y no confinado mediante ensayo de empalme de vigas.}

Senthil P Mathew ${ }^{1}$, Sujatha $A^{1}$, Yashida Nadir ${ }^{2}$

${ }^{1} \mathrm{M}$ Tech Student, ${ }^{2}$ Associate Professor

Structural Engineering Division

Department of Civil Engineering

College of Engineering Trivandrum, Thiruvananthapuram-695016, Kerala, India

Corresponding author mail id: yashidanadir@cet.ac.in

\section{ABSTRACT}

This study investigates the bond strength properties of a green concrete produced by replacing the coarse aggregate by an agricultural by product, coconut shell (CS). The bond between steel reinforcement and coconut shell aggregate concrete was studied by using 60 numbers of beam splice specimens. Confined and unconfined beam splice specimens were used. The effects of rebar diameter of lap splice and types of aggregate were investigated. It was observed that the percentage reduction in bond stress for $16 \mathrm{~mm}$ rebar unconfined beam splice specimens for various percentage replacements of CS from $25 \%$ to $100 \%$, lies in the range of $6-8 \%$ compared to $12 \mathrm{~mm}$ rebar specimens. Whereas, for confined beam splice specimens the range of percentage reduction is $6-10 \%$. For unconfined and confined beam splice specimens, percentage reduction in bond stress for $25 \%$ to $100 \%$ replacement by CS for each $25 \%$ increment was approximately in the range of $2-3 \%, 20-23 \%, 31-34 \%$ and $47-48 \%$ respectively with respect to normal concrete for both $12 \mathrm{~mm}$ and $16 \mathrm{~mm}$ rebar specimens. The percentage increase in bond stress by confining the specimens for various percentage replacements of CS and different size rebar lies in the range of $52-58 \%$.

Keywords: coconut shell aggregate concrete, bond strength of concrete, beam splice test. 
Sustainability, Agri, Food and Environmental Research, (ISSN: 0719-3726), 10(X), 2022: http://dx.doi.org/

\section{RESUMEN}

Este estudio investiga las propiedades de resistencia a la adherencia de un concreto verde producido al reemplazar el agregado grueso por un subproducto agrícola, la cáscara de coco (CS). La unión entre el refuerzo de acero y el hormigón agregado de cáscara de coco se estudió mediante el uso de 60 muestras de empalme de vigas. Se utilizaron muestras de empalme de vigas confinadas y no confinadas. Se investigaron los efectos del diámetro de la barra de refuerzo del empalme traslapado y los tipos de agregado. Se observó que el porcentaje de reducción en la tensión de unión para muestras de empalme de vigas no confinadas de varilla de $16 \mathrm{~mm}$ para varios reemplazos porcentuales de CS del $25 \%$ al $100 \%$, se encuentra en el rango de $6-8 \%$ en comparación con las muestras de varilla de $12 \mathrm{~mm}$. Considerando que, para muestras de empalme de vigas confinadas, el rango de reducción porcentual es del 6 al 10\%. Para muestras de empalme de vigas confinadas y no confinadas, el porcentaje de reducción en la tensión de unión para el reemplazo del $25 \%$ al $100 \%$ por CS por cada incremento del $25 \%$ estuvo aproximadamente en el rango de $2-3 \%, 20-23 \%, 31-34 \%$ y $47-48 \%$ respectivamente con respecto al hormigón normal para probetas de varilla de $12 \mathrm{~mm}$ y $16 \mathrm{~mm}$. El aumento porcentual en la tensión de unión al confinar las muestras para varios reemplazos porcentuales de CS y varillas de refuerzo de diferentes tamaños se encuentra en el rango de $52-58 \%$.

Palabras clave: hormigón agregado de cáscara de coco, resistencia de adherencia del hormigón, ensayo de empalme de vigas.

\section{INTRODUCTION}

Sustainable development is a challenge that civil engineers have an opportunity to address. It is necessary to look forward for sustainable constructions practises. Green materials which could be replenished and recycled can be used for producing sustainable concrete. Major volume of concrete constitutes the aggregates, such as coarse aggregate and fine aggregate. The continued extraction of natural aggregates is leading to its depletion and increased its cost (Saxena and Pofale, 2017; Luhar et al., 2019). Hence, it is necessary to find alternative building materials that can replace natural aggregates in producing concrete. One such alternate material is agricultural byproducts.

Perfect bond between reinforcing bars and concrete is crucial for structural strength and serviceability performance. Adhesion between the reinforcing bar and concrete, frictional resistance and mechanical interlock between the reinforcing bar and concrete, quality and strength of concrete in compression and tension, mechanical anchorage effect of the end of reinforcing bars by its development length, hooks and 
Sustainability, Agri, Food and Environmental Research, (ISSN: 0719-3726), 10(X), 2022: http://dx.doi.org/

splicing, type of aggregates and its maximum size, surface geometry, rebar composition, diameter and spacing of reinforcement etc. are the various factors affecting the bond strength between the reinforcing bar and surrounding concrete (Gunasekaran et al., 2011). Many testing methods such as pull-out test, splice beam test, beam-end test and beam anchorage test etc. (Nadir and Sujatha, 2018a) have been developed to measure bond strength between reinforcing steel bars and concrete. Beam splice method is the full-scale method for bond strength of concrete (Turk and Yildirim, 2003; Turk et al., 2010; Türk et al., 2008).

Numerous research studies were found for the suitability of coconut shell as a construction material and used in concrete as fine aggregate replacement, coarse aggregate replacement, coconut fibre etc. (Kanojia and Jain, 2017; Kumar et al., 2019; Gunasekaran et al., 2013; Khan and Ali, 2018; Nadir and Sujatha, 2018b; Mathew et al., 2020). In this experimental study, the variables considered to investigate the bond strength between steel reinforcement and the surrounding coconut shell aggregate concrete were the effect of confinement, reinforcing bar diameter and percentage of coarse aggregate replacement with coconut shell. Beam splice specimens were used for conducting the study.

\section{MATERIALS AND METHODS}

Preparation of specimens: Total 60 beam splice specimens were cast and tested. Out of the 60 beams, 30 beam specimens were provided with $12 \mathrm{~mm}$ diameter tension reinforcement bars and 30 beams with $16 \mathrm{~mm}$ diameter tension reinforcement bars. In each 30 beams, 15 beams were confined with transverse reinforcement bars and 15 were unconfined without transverse reinforcement. For confined beam specimens, transverse reinforcement was provided using stirrups of $6 \mathrm{~mm}$ diameter bars. Five concrete mixes of $0 \%, 25 \%, 50 \%, 75 \%$ and $100 \%$ coarse aggregate replacement by coconut shells were considered for the study. 3 specimens were cast for each mix. Normal M25 concrete with $12 \mathrm{~mm}$ size coarse aggregate was prepared using the mix proportion $1: 1.47: 1.72$ with water cement ratio 0.42 . Fresh and hardened properties of CSAC were determined for $0,25,50$, 75 and $100 \%$ replacement of CA by CS. The results of the study are shown in

Table 1. Beam splice specimens were prepared by splicing the tension reinforcement bars at the centre of the span. The splice length set for all the beam specimens was $300 \mathrm{~mm}$. This value of splice length was selected so as to develop a steel stress less than yield stress and to ensure splitting mode failure in all the beam specimens. Fig 1 shows the schematic diagram of unconfined beam splice specimen.

Table 1. Fresh and Hardened Properties of CSAC 
Sustainability, Agri, Food and Environmental Research, (ISSN: 0719-3726), 10(X), 2022: http://dx.doi.org/

\begin{tabular}{ccccc}
\hline Mix & $\begin{array}{c}\text { Slump } \\
(\mathrm{mm})\end{array}$ & $\begin{array}{c}\text { Compressive strength } \\
\left(\mathrm{N} / \mathrm{mm}^{2}\right)\end{array}$ & $\begin{array}{c}\text { Split tensile strength } \\
\left(\mathrm{N} / \mathrm{mm}^{2}\right)\end{array}$ & $\begin{array}{c}\text { Flexural strength } \\
\left(\mathrm{N} / \mathrm{mm}^{2}\right)\end{array}$ \\
\hline CSAC 0 & 50 & 36.77 & 2.77 & 5.15 \\
CSAC 25 & 44 & 33.33 & 2.69 & 5.08 \\
CSAC 50 & 38 & 31.14 & 2.64 & 4.97 \\
CSAC 75 & 30 & 28.27 & 2.58 & 4.89 \\
CSAC 100 & 20 & 26.43 & 2.53 & 4.68 \\
\hline
\end{tabular}

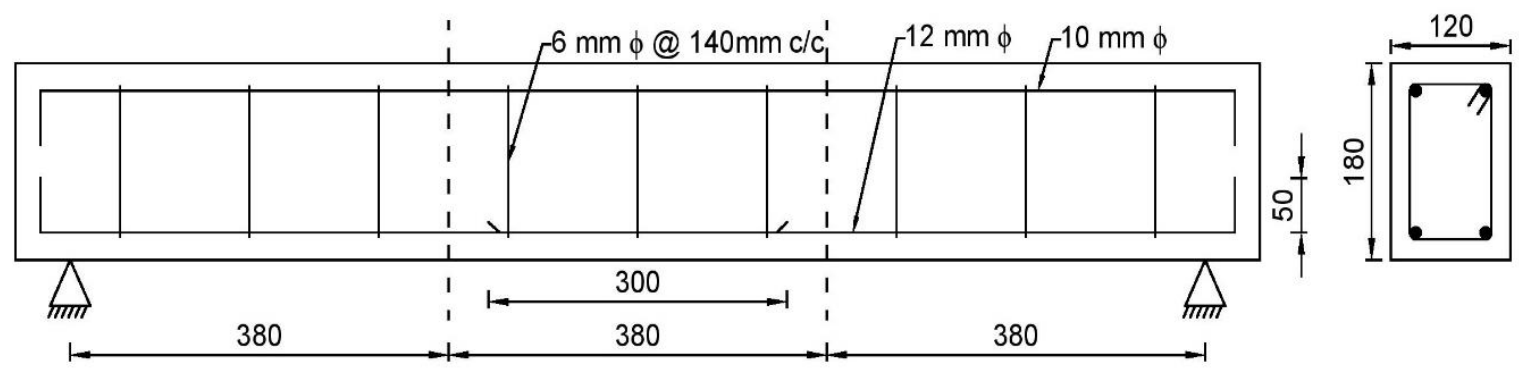

Fig 1. Schematic diagram of confined beam splice specimen

\section{RESULTS AND DISCUSSION}

The notations used for $12 \mathrm{~mm}$ rebar coconut shell aggregate concrete specimens are 12CSAC0, 12CSAC25, 12CSAC50, 12 CSAC75 and 12CSAC100 indicating 0\%, 25\%, $50 \%, 75 \%$ and $100 \%$ replacement of coarse aggregate by coconut shell. Similarly, $16 \mathrm{~mm}$ diameter reinforced bar CSAC specimens are indicated by 16CSAC0, 16CSAC25, $16 C S A C 50,16 C S A C 75$ and 16CSAC100. For unconfined specimens the same notations were used with an additional letter $U$. Elastic cracked section analysis was used to measure the bond strength of the beam splice specimens using the following Eq. 1.

$$
u_{t}=\frac{A_{b} f_{s}}{\pi d_{b} I_{s}}=\frac{f_{s} d_{b}}{4 I_{s}}
$$

where ut=bond strength (MPa), $A b=$ area of one bar, $d b=$ diameter of bar, Is=splice length and fs=stress in tensile steel. Elastic cracked section method was used to find the steel stress fs and determined using Eq. 2 (Menon, 2009).

$$
f_{s}=\frac{M_{\max }}{A_{s t} j d}
$$

where $M m a x=$ maximum bending moment at bond failure, Ast=area of tensile steel, $\mathrm{j}=$ lever arm coefficient and $d=$ effective depth of beam in $\mathrm{mm}$.

The lever arm coefficient was determined by elastic analysis of a fully cracked transformed section method. The results of beam splice test were given in Table 2Table 
Sustainability, Agri, Food and Environmental Research, (ISSN: 0719-3726), 10(X), 2022: http://dx.doi.org/

2. Results of beam splice test.

Table 2. Results of beam splice test

\begin{tabular}{|c|c|c|c|c|}
\hline $\begin{array}{l}\text { Specimen } \\
\text { notation }\end{array}$ & $\begin{array}{l}\text { Ultimate load } \\
\text { Pmax (kN) }\end{array}$ & $\begin{array}{l}\text { Maximum Mid span } \\
\text { deflection }(\delta)(\mathrm{mm})\end{array}$ & $\begin{array}{c}\text { Stress in steel, fs } \\
\text { (MPa) }\end{array}$ & $\begin{array}{l}\text { Bond strength, } \mathrm{u}_{\mathrm{t}} \\
(\mathrm{MPa})\end{array}$ \\
\hline $12 C S A C U 0$ & 54 & 3.1 & 345.89 & 5.19 \\
\hline 12CSACU 25 & 52 & 3.55 & 333.89 & 5 \\
\hline 12CSACU 50 & 42 & 4.01 & 270.15 & 4.05 \\
\hline 12CSACU 75 & 37 & 4.5 & 238.58 & 3.57 \\
\hline 12CSACU 100 & 28 & 4.9 & 180.86 & 2.71 \\
\hline $16 C S A C U 0$ & 64 & 4.01 & 237.88 & 4.76 \\
\hline 16CSACU 25 & 62 & 4.10 & 231.12 & 4.62 \\
\hline 16CSACU 50 & 50 & 4.7 & 186.76 & 3.73 \\
\hline 16CSACU 75 & 44 & 4.4 & 164.84 & 3.29 \\
\hline 16CSACU 100 & 33 & 4.95 & 123.88 & 2.48 \\
\hline $12 \mathrm{CSACO}$ & 84 & 3.66 & 538.05 & 8.07 \\
\hline $12 \mathrm{CSAC} 25$ & 81 & 3.9 & 520.11 & 7.8 \\
\hline $12 \mathrm{CSAC} 50$ & 65 & 4.12 & 418.09 & 6.27 \\
\hline $12 \mathrm{CSAC75}$ & 56 & 4.66 & 361.09 & 5.41 \\
\hline $12 \mathrm{CSAC} 100$ & 44 & 5.3 & 284.21 & 4.26 \\
\hline $16 C S A C 0$ & 99 & 2.18 & 367.98 & 7.36 \\
\hline $16 \mathrm{CSAC} 25$ & 95 & 1.74 & 354.14 & 7.08 \\
\hline $16 \mathrm{CSAC50}$ & 78 & 2.3 & 291.36 & 5.83 \\
\hline $16 C S A C 75$ & 67 & 2.23 & 251 & 5.02 \\
\hline $16 \mathrm{CSAC} 100$ & 51 & 2.33 & 191.45 & 3.83 \\
\hline
\end{tabular}

It can be observed that the ultimate load decreases with increase in CS aggregate percentage. The specimens with larger bar diameter showed increase in ultimate load for corresponding mixes. Mid span deflections were found to be lesser for specimens with larger bar diameter. Percentage decrease in bond stress for $16 \mathrm{~mm}$ rebar unconfined specimens for various percentage replacements of CS lies in the range of $6-8 \%$ with respect to $12 \mathrm{~mm}$ rebar specimens. Whereas, for confined specimens the range becomes $6-10 \%$. For unconfined and confined beam specimens, percentage reduction in bond 
Sustainability, Agri, Food and Environmental Research, (ISSN: 0719-3726), 10(X), 2022: http://dx.doi.org/

stress for $25 \%$ to $100 \%$ replacement by CS for each $25 \%$ increment was approximately in the range of $2-3 \%, 20-23 \%, 31-34 \%$ and $47-48 \%$ respectively with respect to normal concrete for $12 \mathrm{~mm}$ and $16 \mathrm{~mm}$ rebar specimens. The percentage increase in bond stress by confining the specimens for various percentage replacement and different size rebar in the present study lies in the range of $52-58 \%$. The face-and-side split failure was observed as the mode of failure in all the beam specimens. The crack width of specimens with 12 $\mathrm{mm}$ diameter bar was higher than that of $16 \mathrm{~mm}$ diameter bar specimens. Confinement makes the specimens stronger and hence a smaller number of cracks was developed. The crack patterns of the beam splice specimens with $12 \mathrm{~mm}$ diameter bar for different CSAC mixes are shown in Fig 2.
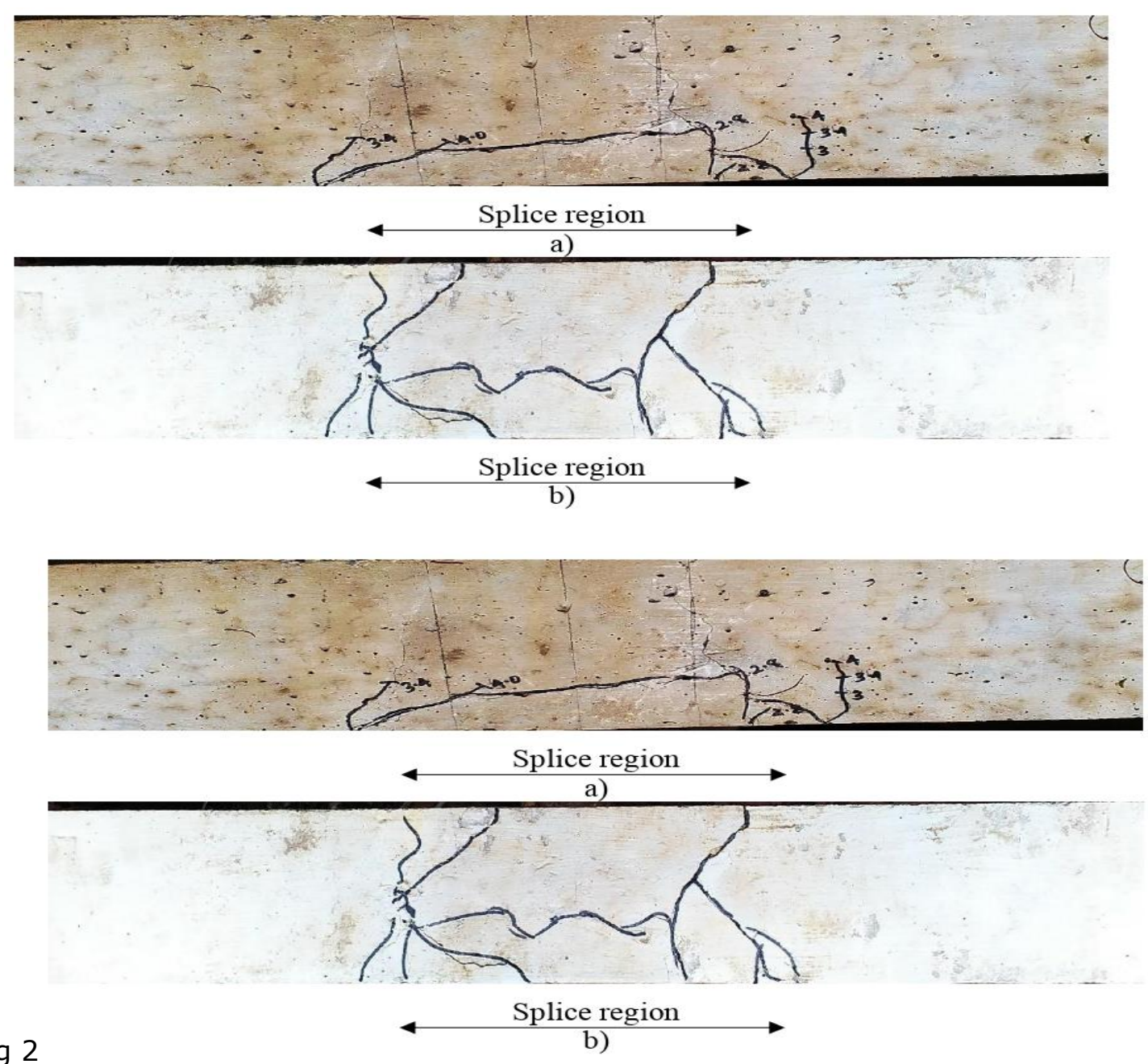

Fig 2

b)

Fig 2. Crack patterns of 12 CSACU0 beam splice specimens a) Side view of the beam $b$ ) Bottom view of the beam 
Sustainability, Agri, Food and Environmental Research, (ISSN: 0719-3726), 10(X), 2022: http://dx.doi.org/

The following conclusions were drawn from the present study. For unconfined beam splice specimens, percentage reduction in bond stress for12CSAC25, 12CSAC50, 12 CSAC75 and 12CSAC100 specimens was approximately $2 \%, 21 \%, 31 \%$ and $48 \%$ respectively with respect to normal concrete. For unconfined beam splice specimens, percentage reduction in bond stress for 16CSAC25, 16CSAC50, 16CSAC75 and $16 \mathrm{CSAC} 100$ specimens was approximately $3 \%, 22 \%, 31 \%$ and $48 \%$ with respect to normal concrete. For confined beam splice specimens, percentage reduction in bond stress for 12 CSAC25, 12 CSAC50, 12CSAC75 and 12 CSAC 100 specimens was approximately $3 \%$, $23 \%, 34 \%$ and $48 \%$ respectively with respect to normal concrete. For confined beam splice specimens, percentage reduction in bond stress for 16CSAC25, 16CSAC50, 16 CSAC75 and 16CSAC100 specimens was approximately $3 \%, 20 \%, 31 \%$ and $47 \%$ respectively with respect to normal concrete. Confinement increased the bond strength percentage in the range of 54-58 \% for $12 \mathrm{~mm}$ and $16 \mathrm{~mm}$ rebar specimens. Bond strength slightly decreased with increase in bar diameter. For unconfined beam splice specimens, percentage reduction in bond stress for 16CSAC25, 16CSAC50, 16CSAC75 and $16 C S A C 100$ specimens was approximately $6-8 \%$. For confined specimens this range becomes $6-10 \%$.

\section{REFERENCES}

Gunasekaran, K., Annadurai, R., and Kumar, P.S. (2013). Plastic shrinkage and deflection characteristics of coconut shell concrete slab: Construction and Building Materials, Vol. 43, pp. 203-207, DOI: 10.1016/j.conbuildmat.2013.02.019.

Gunasekaran, K., Kumar, P.S., and Lakshmipathy, M. (2011). Mechanical and bond properties of coconut shell concrete: Construction and Building Materials, Vol. 25, No. 1, pp. 92-98, DOI: 10.1016/j.conbuildmat.2010.06.053.

Kanojia, A., and Jain, S.K. (2017). Performance of coconut shell as coarse aggregate in concrete: Construction and Building Materials, Vol. 140, pp. 150-156, DOI: 10.1016/j.conbuildmat.2017.02.066.

Khan, M., and Ali, M. (2018). Effect of super plasticizer on the properties of medium strength concrete prepared with coconut fiber: Construction and Building Materials, Vol. 182, pp. 703-715, DOI: 10.1016/j.conbuildmat.2018.06.150.

Kumar, V.R.P., Gunasekaran, K., and Shyamala, T. (2019). Characterization study on coconut shell concrete with partial replacement of cement by GGBS: Journal of Building Engineering, Vol. 26, No. March, p. 100830, DOI: 10.1016/j.jobe.2019.100830.

Luhar, S., Cheng, T.W., and Luhar, I. (2019). Incorporation of natural waste from agricultural and aquacultural farming as supplementary materials with green 
Sustainability, Agri, Food and Environmental Research, (ISSN: 0719-3726), 10(X), 2022: http://dx.doi.org/

concrete: A review: Composites Part B: Engineering, Vol. 175, No. May, p. 107076, DOI: $10.1016 /$ j.compositesb.2019.107076.

Mathew, S.P., Nadir, Y., and Arif, M.M. (2020). Experimental study of thermal properties of concrete with partial replacement of coarse aggregate by coconut shell: Materials Today: Proceedings, Vol. 27, No. xxxx, pp. 415-420, DOI: 10.1016/j.matpr.2019.11.249.

Menon, D. (2009). Advanced Structural Analysis, Illustrated Ed. Alpha Science International.

Nadir, Y., and Sujatha, A. (2018a). Bond strength determination between coconut shell aggregate concrete and steel reinforcement by pull-out test: Asian Journal of Civil Engineering, Vol. 19, No. 6, pp. 713-723, DOI: 10.1007/s42107-018-0060-1.

Nadir, Y., and Sujatha, A. (2018b). Durability Properties of Coconut Shell Aggregate Concrete: KSCE Journal of Civil Engineering, Vol. 22, No. 5, pp. 1920-1926, DOI: $10.1007 / \mathrm{s} 12205-017-0063-6$.

Saxena, S., and Pofale, A.D. (2017). Effective Utilization of Fly Ash and Waste Gravel in Green Concrete by Replacing Natural Sand and Crushed Coarse Aggregate: Materials Today: Proceedings, Vol. 4, No. 9, pp. 9777-9783, DOI: 10.1016/j.matpr.2017.06.266.

Türk, K., Benli, A., and Calayir, Y. (2008). Bond strength of tension lap-splices in full scale self-compacting concrete beams: Turkish Journal of Engineering and Environmental Sciences, Vol. 32, No. 6, pp. 377-386, DOI: 10.3906/sag-1302132.

Turk, K., Karatas, M., and Ulucan, Z.C. (2010). Effect of the use of different types and dosages of mineral additions on the bond strength of lap-spliced bars in selfcompacting concrete: Materials and Structures/Materiaux et Constructions, Vol. 43, No. 4, pp. 557-570, DOI: 10.1617/s11527-009-9511-1.

Turk, K., and Yildirim, M.S. (2003). Bond strength of reinforcement in splices in beams: Structural Engineering and Mechanics, Vol. 16, No. 4, pp. 469-478, DOI: 10.12989/sem.2003.16.4.469.

Received: $30^{\text {th }}$ January 2021; Accepted: $10^{\text {th }}$ March 2021; First distribution: 01th April 2021 